\title{
The Effect of Project Based Learning Models on Improving Student Learning Results on Entrepreneurship Education
}

\author{
Muhamad Affandi* \\ Community Education Department \\ Indonesia University of Education \\ Bandung, Indonesia \\ *affandimuhamad.pls@upi.edu
}

\author{
Takahashi Mitsuru \\ Tohoku University \\ Sendai, Japan \\ taka-man@sed.tohoku.ac.jp
}

\author{
Mustofa Kamil, Ace Suryadi \\ Community Education Department \\ Indonesia University of Education \\ Bandung, Indonesia \\ mustofa.kamilun@upi.edu, acesuryadi@upi.edu
}

\begin{abstract}
The development of learning models cannot be separated from the aspects of policy and legality in the form of curriculum. Through a structured and functional curriculum with the learning needs of the community. Innovative and participatory models will be easier to implement in a learning setting. Changes to the curriculum in the sphere of community education stimulate practitioners to prepare their resources to support the implementation of the curriculum itself. In compiling the planning and implementation of equivalence education learning, it is necessary to integrate competency attitudes, knowledge, and skills as a whole through comprehensive performance. However, at the implementation level, several problems were found. The results of the identification of problems in the implementation of equivalence education in entrepreneurship material in Palangka Raya show that the organizers are more oriented to academic needs, meaning that the content of skills in entrepreneurship learning has not yet been found. Departing from this phenomenon, the researcher initiated a project-based learning model as an innovative learning model that emphasizes contextual learning through various complex activities. This research was conducted using a quantitative approach with a pre-experimental method whose results are dependent variables that are not solely influenced by independent variables. The research design used is one group pre-test-post-test design with a sample of 30 students in package $C$ at Grade XI. Through the treatment given, it is concluded that the project-based learning model is effective for improving entrepreneurial learning outcomes as evidenced by an increase in the average value of the post-test compared to the pre-test by comparison $\mathrm{O} 1 \times 02(73,8-60,2=13,6)$.
\end{abstract}

Keywords-project based learning, entrepreneurship, equivalence education

\section{INTRODUCTION}

The development of learning models cannot be separated from the aspects of policy and legality in the form of curriculum. Through a structured and functional curriculum with the learning needs of the community. Innovative and participatory models will be easier to implement in a learning setting. Dynamics of the development of curriculum implementation policies in Indonesia since 1947 until today is based on the results of analysis, evaluation, predictions and various challenges faced both internally and externally [1]. In this context, the curriculum as an educational policy product in Indonesia must be dynamic, contextual and adaptive to the progress of the development of science and technology.

In its current development, the 2013 curriculum as the latest product is an embodiment of the basic principles of the change and continuity curriculum, believed to be a strategic policy in preparing and facing challenges and demands of the future Indonesian people. The 2013 curriculum policy will be able to play the adjusted or adaptive function, which is a curriculum that is able to direct its students to be able to adjust themselves to the environment, both the physical environment and social environment that is constantly changing. The 2013 curriculum integrates three areas of competence, namely attitudes, knowledge and skills in its implementation.

In the scope of community education, especially equivalence education programs, the curriculum also continues to experience development as a representation of the policies announced by the government. Community education as one of the educational channels at this time is not only located as a substitute, supplementary or enhancer of the school education 
pathway. Community education is now an alternative for the community to acquire a new type of innovative knowledge and skills, which may not be found in the formal education.

Furthermore, the application of the 2013 curriculum as a substitute for the Education Unit Level Curriculum (SBC), in primary and secondary education is no exception equivalence education brings the impact of change. One of them is the education unit as one of the implementers of the education process must be able to prepare resources to support the implementation of the 2013 curriculum. In compiling the planning and implementation of equivalence education learning, it is necessary to integrate competency attitudes, knowledge, and skills as a whole through comprehensive performance. Educators must be able to design learning and provide learning resources such as learning facilities and infrastructure, teaching aids, materials, media, learning resources, social and natural environment, and other learning resources.

Learning resources that are prepared must be appropriate and meet the needs of educators and students as well as community conditions. One source of learning that is quite central in the success of students is teaching material. Teaching materials in equivalence education must certainly be able to facilitate students in understanding the subject matter. In order for the teaching material to be easily understood by students, one alternative is the material in the teaching material must be able to connect between what is learned with how the knowledge will be used or utilized in life. The teaching material that is compiled is expected to pay attention to the context of the students and relate the material to real life. The real context of the lives of students includes physical background, family, social conditions, politics, religion, culture and other realities of life.

The results of the need assessment of the three community education units in the City of Palangka Raya showed that the implementation of the equivalence education program was still focused on the substitute function for formal education. This means that optimization related to the provision of productive skills education is still minimal. Referring to the Minister of Education and Culture Regulation No. 14 of 2007 concerning the Implementation of Equivalence Education Standards, it is explained that graduates of the $\mathrm{C}$ package program are also required to have functional skills competencies that can be implemented in their daily activities, especially with regard to improving living standards and economic conditions.

Referring to the regulation above, and supported by Regulation of the Minister of Education of the Republic of Indonesia Number 3 of 2008 concerning the standard process of education implementation, the development team tried to describe the findings of problems related to several components in learning equivalence education, including the tutor component as an educator, student activeness, use of learning methods and optimization of study time.

In this component, researchers found problems with tutor competence as educators. Tutors as equivalence educators as well as internalize entrepreneurial values in students, are not only required to master the material; but also able to manage classes and create a good flow of interactions. However, the facts on the ground show that organizers and tutors are more oriented to academic needs, meaning that the content of skills in entrepreneurship learning has not yet been found.

In the component method and learning time, tutors in the implementation of equivalence education in the scope of entrepreneurship introduction use the direct practice method. That is because almost all students who attend the training are adults who prefer practice over theory. So students are directed more to practice with an allocation of time 4 hours per day. In addition, in the implementation process, the facilitator also conducts material evaluations so that in the future students are able to produce maximum results both in terms of colour, shape and technical manufacture.

The next component is the activeness of students. This is where researchers find an explicit problem that urges immediate solution. Students follow the equivalency education package $\mathrm{C}$ on the basis of their own interests and needs, so students not only have to be active in the classroom, but they also have to hone their abilities independently and repeatedly when not in a learning situation. The process will greatly assist them in understanding the material provided by the tutor, so that the expected competencies can be achieved on time.

Students as subjects of equivalence education package C, especially in the introduction of entrepreneurship in the three preliminary study locations are still not fully able to achieve the entrepreneurial competencies listed in the learning tools.

The limited achievement of these competencies is caused by the non-functional material delivered by the tutor as a learning resource. Students who have mastered the concepts and competencies of introducing entrepreneurship seem difficult to implement the knowledge they have acquired due to the limited resources and entrepreneurs who are close to their daily lives.

Referring to the phenomena and challenges, it is needed an understanding of managers and educators about the characteristics of the models used in learning activities in equivalence education package $\mathrm{C}$, especially in the introduction of entrepreneurship. Researchers collaborate with managers and technical informants to implement the Project Based Learning $(\mathrm{PjBL})$ model as an innovative learning model that emphasizes contextual learning through various complex activities

Through the results of previous research, it is said that project-based learning is a pedagogical activity that involves students in applying and developing various concepts, skills and techniques to solve everyday problems; and implemented in elementary schools and secondary schools [2].

Other research states that project based learning has advantages including: allowing parallel thinking, being independent, accepting changes and differences, utilizing technology and promoting the principles of lifelong learning. 
Even so, there are also some weaknesses of this model, including difficulties in managing time, measurement of complicated learning achievement, difficulty in breaking conventional learning styles, and this model does not necessarily fit all the characteristics of students [3].

South Africa has a strategy of growing entrepreneurial values through training which includes curriculum design, delivery methods and assessment measures. Through research in the country, innovative entrepreneurial learning strategies must be oriented and implemented on a project-based basis.

The application of project based learning in South Africa is carried out in formal schools and has the result of shifting the role of learners from passive to active; students have entrepreneurial activities/projects which are then presented to their educators as a form of growing entrepreneurial character [4].

In other studies in Southampton, project based learning activities are carried out at the tertiary level with the aim of providing benefits to students, who expect business skills to be implemented in their daily activities [5].

The same concept was also implemented in research in New York, where project based learning is interpreted as an innovative approach that teaches diverse critical strategies to achieve success in the $21^{\text {st }}$ century. Learners determine their own learning experiences through inquiry, collaborative learning and various studies that reflect their knowledge. Learning with this PjBL model is carried out by utilizing technology, connections with the real world and measuring the effectiveness of learning outcomes based on the success of the project from students. The result is students are able to evaluate learning independently through the measurement of how they communicate, think, hear and provide solutions to the problems of their peers [6].

Other research in Indiana in the United States using the project based learning model in higher education is to improve students' attitudes and understanding of lecture material through the implementation of various kinds of science into projects and daily activities. As a result, it is evident that the use of the PjBL model is able to improve student memory of lecture material, which is indicated by improving learning outcomes at the end of the semester [7].

Taiwan utilizes a project-based learning model on a school basis, specifically in grade 5 (ages 10 to 11 years), through a scientific project called SciCamp (science camp) as an extracurricular activity in formal schools. SciCamp is done by integrating students' knowledge in classroom learning with technology that is already familiar with them and then used in solving problems in a particular project [8].

Some of the above research initiates researchers to implement project based learning in community education as a novelty through interactive learning activities that are more student-cantered. In practice, tutors will later play more roles as facilitators, involving students and alumni who already have entrepreneurial experience as peer tutors, so that they are expected to have more emotional closeness with students. PjBL itself is a comprehensive learning approach in learning that is designed to involve students in identifying factual focus/problems [9].

Referring to these problems, this research was conducted to answer the following research questions:

- What is the procedure for developing a project-based learning model on entrepreneurship education?

- How is the accessibility of educators and students in the application of project-based learning models in entrepreneurship education?

- How the effectiveness of the project-based learning model, especially related to increasing entrepreneurial competence in students themselves?

\section{A. Project Based Learning}

Project Based Learning is one of the project-oriented learning models that is based on questions or problems that arise in the learning environment; so that it stimulates students' involvement in the process of planning, problem solving, decision making to the formulation of learning objectives. The concept will make students active because they feel involved at each stage of learning. In connection with this understanding, it is stated that project based learning is a pedagogical activity that involves students in applying and developing various concepts, skills and techniques to solve everyday problems; and implemented in elementary schools and secondary schools [2].

Furthermore, other concepts about project based learning are conveyed as innovative learning methods or approaches, which emphasize contextual learning through various complex activities, such as giving students freedom to explore and plan learning activities, implement projects collaboratively and ultimately produce a product [3].

In line with this definition, project based learning is interpreted as a learning model that uses projects as a learning tool to achieve competency attitudes, knowledge and skills [6]. The emphasis of learning lies in the activities of students to solve problems by applying skills, researching, analysing to presenting learning products based on real experience.

In the implementation order, the project based learning model has several stages, including: start with the essential question, design a plan for the project, create a schedule, monitor the students and the progress of the project, assess the outcome, dan Evaluate the experience [7].

As one of the learner-oriented learning models, project based learning has several principles, including: centrality, driving question, constructive investigation, autonomy, dan realism [10]. 


\section{B. Entrepreneurship Education}

Education is an important aspect that cannot be separated from human development. Educational activities that are involved have a very large contribution in preparing quality Human Resources and able to keep up with the times. Basically, the education process is one of the efforts made by humans in forming a competent and globally competitive person.

Entrepreneurship is a word that comes from two languages, namely French and English. In French, an entrepreneur (entreprende) means adventurer, risk taker or entrepreneur; which further is also interpreted as "celui qui entemprend quelque chose" which has the meaning of someone who is active and achieves something [11]. Meanwhile according to English, entrepreneurship means "Adventurer, he that seeks occasion of hazard; hethat pust himself him the hand of chance" [11]. Successfully taking the risk of being the property of entrepreneurs because they are required to be brave and ready if done that do not yet have the value of attention in the market.

Furthermore, entrepreneurship education is interpreted as a process of instilling creativity and innovation in overcoming problems, various risks and opportunities for success. Entrepreneurship education teaches the cultivation of entrepreneurial values that shape the character and behaviour for entrepreneurship so that students can be creative and productive [12].

\section{Equivalent Education}

Based on the Law of the Republic of Indonesia Number 20 Year 2013 concerning the National Education System Article 26 Paragraph (3), and its explanation that equivalence education is a non-formal education program that organizes public education movements equivalent to SD/MI, SMP/MTs, and SMA/MA which includes Package A, Package B, and Package C programs [13].

Equivalence education includes the Package A program equivalent to SD / MI, Package B equivalent to SMP / MTs, and Package C equivalent to SMA / MA with an emphasis on mastering knowledge and functional skills, as well as developing the attitudes and professional personality of students. The learning process is carried out using learning that is more inductive, constructive, and also independent learning through talking about environmental challenges and finding solutions by bringing together knowledge that is not related to more relevant to everyday life.

Non-formal education outcomes can be valued on a par with the results of formal education programs after going through an equalization assessment process by an institution appointed by the Government or the Regional Government with reference to the National Education Standards [13].

\section{MethodS}

This research was conducted using a quantitative approach with a pre-experimental method whose results are dependent variables that are not solely influenced by independent variables. This happens because there are no control variables, and the sample is not chosen randomly [14]. The selection of the pre-experimental method is expected to be able to uncover the mechanism of implementing a project-based learning model in entrepreneurship education developed by researchers. The research design is a design of how this research is carried out. The research design used in this study is one group pretest-post-test design [15].

The instruments used were observation, questionnaires and tests of learning outcomes that were first tested for eligibility through validity, reliability and public test. This study is an interpretation of data from observations of the development process as well as the implementation of a project based learning model through the observation process of researchers in the field, as well as questionnaire data conducted at the end of the learning process. Meanwhile, the data showing the growth of social entrepreneurship spirit were obtained based on the results of the pre-post test conducted before and after the treatment process ended. As for this measurement, the researchers used the One Group Pretest-Posttest Design approach. This approach is used with the consideration that the results of the research can be known accurately, because they can be directly compared with the conditions before and after being treated.

This research was carried out in Palangka Raya, precisely in three community education unit institutions, namely PKBM Luthfillah, PKBM Candra Kirana and PKBM Katimpun. The population in this study were 30 package $C$ students in class XI who are adults with an age range of 14 s.d. 45 years with the specifications of 10 PKBM Luthfillah students, 10 PKBM Candra Kirana students and 10 PKBM Katimpun students.

Sampling technique based on research subjects if less than 100 people then all taken from the population. So the sample used in this study uses a total sample. The total sample is a sample of the amount of the population [16].

The purpose of this study is to identify social entrepreneurship skills that students have, the conceptual design of project-based learning models to be applied, implement project-based learning models applied as an effort to improve social entrepreneurship, and analyse project-based learning models in fostering social entrepreneurship in equivalent education students in Palangka Raya (Table 1,2).

TABLE I. RESEARCH VARIABLES

\begin{tabular}{|l|l|}
\hline $\mathrm{x}$ & Project based learning model \\
\hline $\mathrm{y}$ & Learning outcomes of entrepreneurship education \\
\hline
\end{tabular}


TABLE II. RESEARCH HYPOTHESIS

\begin{tabular}{|l|l|}
\hline $\mathrm{H}_{\mathrm{i}}$ & $\begin{array}{l}\text { There is a significant influence between the application of the } \\
\text { project-based learning model on the learning outcomes of } \\
\text { entrepreneurship education in package C students in Palangka } \\
\text { Raya }\end{array}$ \\
\hline $\mathrm{H}_{\mathrm{o}}$ & $\begin{array}{l}\text { There is no significant effect between the application of the } \\
\text { project-based learning model on the learning outcomes of } \\
\text { entrepreneurship education in package C students in Palangka } \\
\text { Raya }\end{array}$ \\
\hline
\end{tabular}

\section{FINDINGS AND DISCUSSION}

\section{A. Worthiness Test}

This research is a form of treatment through the application of innovative learning models with project orientation as a solution to the learning problems that have been identified previously, especially in the implementation of entrepreneurship education at the package $\mathrm{C}$ level. The use of the project-based learning model is based on the characteristics and potential of students as members of the community.

In an effort to measure the results of research, researchers first conduct a feasibility test of models and instruments with several steps, including:

- Validity test uses the product moment formula, with details of the results of 25 valid instrument items $\left(r_{\text {count }}>r_{\text {table }}\right)$ that is the number item $2,3,4,5,6,7,8,9$, $10,11,12,13,14,15,16,17,18,19,20,21,26,27,28$, 29 and 30; and 5 drop instrument items $\left(\mathrm{r}_{\text {count }}<\mathrm{r}_{\text {table }}\right)$ that is number $1,22,23,24,25$.

- Reliability test, is a calculation of the determination or consistency of the questionnaire using the Alpha formula. The use of this formula is adjusted to the scoring technique carried out on each item in the instrument. The reliability test results obtained $r_{\text {count }}$ 0,84636 . Refers to the opinion of experts who state that an instrument is said to be reliable if the coefficient value obtained $>0,60$ [17]. Calculation results of the $r_{\text {count }}$ show that $1,03427>0.06$ which means that this questionnaire has high reliability criteria. So this questionnaire is said to be reliable.

- Public Test, carried out with a t-test aimed at analysing the effectiveness of the tested model [15]. Also, likert scale is used to analyse public tests and model tools. Based on data analysis of the results of the level of feasibility and attractiveness (feasibility) of the model script and the model supporting tools obtained a minimum index of $\%=60$, or with a category that is eligible to apply. While the results of the model effectiveness test using paired sample t-test analysis, it was found that the value of $t_{\text {count }}>t_{\text {table }}$ and $P$ value (two tail) $<0.05$. Because $t_{\text {count }}>t_{\text {table }}$ and $P$ value (two tails) $<0.05$, it can be concluded that the post-test scores of academic ability are better than the pre-test scores; so it can be stated that this model is effective to apply.

\section{B. Discussion of Observation Data}

Through observations, several findings have been found that students can understand the entrepreneurial learning objectives and be able to integrate with their daily activities. Students also seem to be able to understand the context of SK, $\mathrm{KD}$ and indicators of achievement of competence in the material. Through this project-based learning students also have a strong desire to learn, and are able to develop their own learning strategies. As for the other observation points, it is obtained the fact that students still need tutors in solving their problems in learning.

In other observation items, the fact is that in addition to being active during the learning process, students also realize their learning goals and direct their learning process towards achieving those goals. However, in the ability measurement activity, students are known to still need participation from their tutors.

Through other observation items, it is described that students are able to correct their mistakes during the learning process and are able to see the results of what they have learned in accordance with the planned objectives. In addition, the students in package $\mathrm{C}$ are also able to show their learning outcomes and take responsibility for their work. As for the assignments in the scope of learning, it is known that the role of the tutor is still quite significant.

\section{Discussion of Questionnaire Data}

1) Tutor activities: This component of tutor activities broadly intends to describe and also reveal the activities of tutors during independent learning, which is seen from the perspective of students (samples). Based on data obtained through a questionnaire, the following facts are found:

- Responses to statement number 1 indicate that tutors involved students in making learning contracts, even though there were 9 people who felt they were not fully involved.

- Statement items number 2 and 21 show that in addition to using existing learning resources, students are also asked to look for alternative learning resources as support for learning.

- Item number 3 describes that the majority of students feel involved in choosing the sub-topics to be studied.

- Item number 4, 5 and 6 indicate that students are given authority to determine when and how long they study at each meeting.

- Item number 7 explains that students participate well in learning activities as stated in the learning contract. Whereas point number 8 and 9 emphasize that they also use various alternative learning resources and coordinate with peer tutors. 
- Statement items $10,11,12$ and 13 reveal the fact that periodically, students always report the development of learning and their difficulties in learning to their tutors.

- Statement item number 14 obtains data that all students submit their mandatory tasks to tutors as a form of assessment/evaluation; while tutor is obliged to explain and provide input related to the answers to the task.

2) Student activities: The student activity component seeks to find facts about the various learning dynamics faced by the students themselves. Data collection related to these activities was obtained through a questionnaire that was responded directly by the students as research samples. The findings are related to this namely:

- Statement items 16 and 17 emphasize that tutors always tell students about the benefits of learning with certain themes that are close to their daily lives. Tutors also always ask students the readiness to learn.

- Item number 19 indicates that the tutor always asks students' readiness to learn. This is very important because it will determine the quality of learning itself.

- Item number 20 states that the tutor always ensures the order of the subtopics of the obligations and rights of the state and citizens which will be studied in sequence. Although students are given the authority to choose the material, but the tutor also always controls the achievement of understanding of the material/sub-topic.

- Statement items 22 and 23 reveal the fact that the tutor always sees and evaluates every learning activity carried out by students. In addition to fulfilling the learning component, it is important to motivate students to feel constantly taken care of by their tutors.

- Statement items number 24 and 25 provide data that the tutor always gives feedback in order to improve and progress learners.

\section{Discussion of Competency Test Result Data}

In learning outcomes activities in relation to increasing entrepreneurial competence itself, it is explained that the competencies in question include entrepreneurial knowledge, entrepreneurial attitudes competencies, competencies to create entrepreneurial opportunities, entrepreneurial management competencies and social competencies in entrepreneurship [18].

The explanation of the comparison of students' package $\mathrm{C}$ knowledge towards learning entrepreneurship education through competency test tests, namely:

After obtaining a pre-test score from each student, the results of the development of the data were carried out using a post-test of the citizens learning package $\mathrm{C}$ to find out knowledge about the entrepreneurial material, while the average value obtained was 77.5.
After conducting the results of the pre-test and post-test values, the next method is to use an experimental research method with the approach or type of One-group Pre-testPostest Design. This method is used because the results of research can be known accurately, because it can compare with the situation before being given treatment. The comparison of the pre-test and post-test scores on the entrepreneurship competency test. For more details, can be seen in the Figure 1:

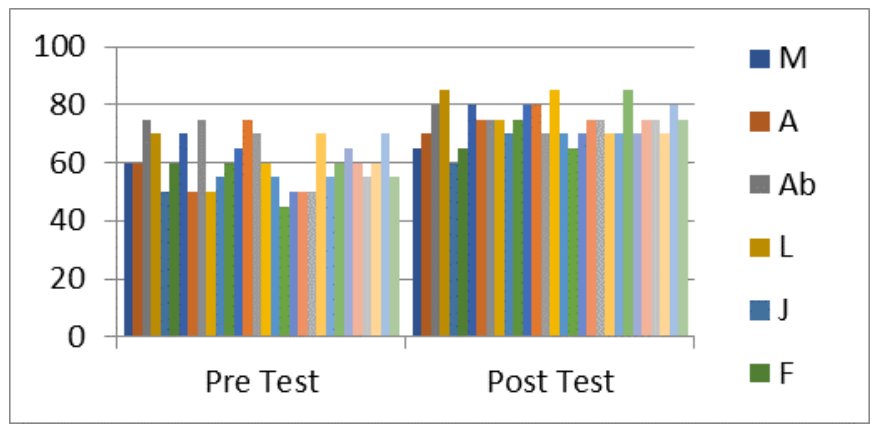

Fig. 1. Comparison of pre-test and post-test value of research samples which indicates an increase in the pre-test and post-test scores, from 60.2 to 73.8 (an increase of 13.6)

The graphic shows that the post-test value has increased from the pre-test value which is the pre test value of 60,2 with a post-test value of 73,8 which is 13,6 . To be able to compare entrepreneurial material knowledge from the value of the results at the time of the pre-test and from the value of the results after the post-test.

Then the data is processed using a simple experimental formula with one group pre-test-post-test design approach, $\mathrm{O} 2$ - $\mathrm{O} 1(\mathrm{O} 2$ = post-test value and $\mathrm{O} 1=$ pre-test value $)$. Referring to the formula, 13,6 results are obtained which is the result of reducing the value of post-test $(73,8)$ with pre-test value $(60,2)$. This data indicates that through the implementation of the project-based learning model has a positive impact on entrepreneurial learning outcomes of students in Package $\mathrm{C}$ Class XI in Palangka Raya.

\section{CONCLUSION}

Based on the results of the study, several things can be discussed as answers to the research questions asked, including:

- Model development procedures are carried out by involving students and the community through identification of potentials and abilities. At the implementation and evaluation stages, this model also requires positive collaboration from the community, especially peer tutors to measure student learning outcomes.

- Through the data collection activities carried out, the fact is obtained that educators and students are able to take advantage of this model because of the ease of access and sharing roles in learning and mentoring situations. 
- The project-based learning model is effective for improving entrepreneurial learning outcomes as evidenced by an increase in the average post-test score compared to the pre-test.

\section{ACKNOWLEDGMENT}

The writers would like to extend their gratitude to the chairman of Community Education Department, Universitas Pendidikan Indonesia by the time this article can be published and presented on The First Transnational Webinar on Adult and Continuing Education (TRACED) in UPI Bandung.

\section{REFERENCES}

[1] D.A. Katuuk, "Manajemen Implementasi Kurikulum: Strategi Penguatanimplementasi Kurikulum 2013," J. Cakrawala Pendidik., 2014, doi: 10.21831/cp.v1i1.1858.

[2] M.L. Nation, "Project-based learning for sustainable development," J. Geog., 2008, doi: 10.1080/00221340802470685.

[3] G.L. Danford, "Project-based learning and international business education,” J. Teach. Int. Bus., 2006, doi: 10.1300/J066v18n01_02.

[4] M. Botha, "A project-based learning approach as a method of teaching entrepreneurship to a large group of undergraduate students in South Africa," Educ. as Chang., 2010, doi: 10.1080/16823206.2010.522059.

[5] R. Hanney, "Doing, being, becoming: a historical appraisal of the modalities of project-based learning," Teach. High. Educ., 2018, doi: 10.1080/13562517.2017.1421628.

[6] S. Bell, "Project-Based Learning for the 21st Century: Skills for the Future," Clear. House A J. Educ. Strateg. Issues Ideas, 2010, doi: $10.1080 / 00098650903505415$.
[7] E.K. Perrault and C.A. Albert, "Utilizing project-based learning to increase sustainability attitudes among students," Appl. Environ. Educ. Commun., 2018, doi: 10.1080/1533015X.2017.1366882.

[8] L J. ChanLin, "Technology integration applied to project-based learning in science," Innov. Educ. Teach. Int., 2008, doi: 10.1080/14703290701757450.

[9] P.C. Blumenfeld, E. Soloway, R. W. Marx, J. S. Krajcik, M. Guzdial, and A. Palincsar, "Motivating Project-Based Learning: Sustaining the Doing, Supporting the Learning," Educ. Psychol., 1991, doi: 10.1080/00461520.1991.9653139.

[10] J.W. Thomas and P.D, "A Review of Research on Project-Based Learning," Learning, 2000.

[11] M. Casson, The entrepreneur: An economic theory, second edition. 2003.

[12] S. Farny, S. H. Frederiksen, M. Hannibal, and S. Jones, "A CULTure of entrepreneurship education," Entrep. Reg. Dev., 2016, doi: 10.1080/08985626.2016.1221228.

[13] Depdiknas, "Undang-undang sistem pendidikan nasional," 2003.

[14] A. Suharsimi, Prosedur Penelitian: Suatu Pendekatan Praktik (Edisi Revisi). 2013

[15] J. Creswell, "Qualitative, quantitative, and mixed methods approaches," in Research design, 2013.

[16] W. Surakhmad and W. Surakhmad, "Pengantar penelitian ilmiah : dasar, metode dan teknik / Winarno Surakhmad," 1. PENELITIAN,Pengantar Penelit. Ilm. dasar, Metod. dan Tek. / Winarno Surakhmad, 1989, doi: 0253-9772(2006)10-1294-05 [pii].

[17] M.S. Knowles, "Self-directed learning: a guide for learners and teachers," Selfdirected learning A guide for learners and teachers. 1975.

[18] A. Malekipour, R. Hakimzadeh, M. Dehghani, and M. R. Zali, “Analysis of entrepreneurial competency training in the curriculum of bachelor of physical education in universities in Iran," Cogent Educ., 2018, doi: 10.1080/2331186X.2018.1462423.. 